\title{
Acute coronary syndromes in young women - the scale of the problem and the associated risks
}

\author{
Maciej Bęćkowski \\ $2^{\text {nd }}$ Clinic of Coronary Heart Disease - Cardinal Stefan Wyszyński Institute of Cardiology, Warsaw, Poland \\ Kardiochirurgia i Torakochirurgia Polska 2015; 12 (2): 134-138
}

\begin{abstract}
Diseases of the cardiovascular system mainly affect elderly patients, but they are increasingly often encountered in young individuals. It is estimated that 1 in 20 patients with ischemic heart disease is under the age of 45 years. Only $20 \%$ of them are women. According to the PL-ACS register, cases of acute coronary syndromes in young women represent $0.6 \%$ of all acute coronary syndrome cases.

The most common etiology is atherosclerosis (80\%). Other causes include dissections and spasms of the coronary arteries as well as clotting disorders. Smoking tobacco is the most important risk factor, followed by hypertension, hyperlipidemia, and diabetes. The long-term prognosis is usually favorable, but it deteriorates significantly in the event of complications. The literature on this subject is not extensive. Most data come from non-randomized studies of young patients conducted regardless of sex.

The purpose of this paper is to present the problem posed by acute coronary syndromes in young women.
\end{abstract}

Key words: coronary artery disease, myocardial infarction, young women.

\section{Introduction}

For many years, diseases of the circulatory system have constituted the primary cause of mortality in Western countries, including Poland. Reports of the World Health Organization indicate that they are responsible for approximately $40 \%$ of all deaths in Europe (men: $36.2 \%$, women: 43.3\%) [1]. According to the Department of Demographic Studies of the Polish Central Statistical Office (GUS, Gtówny Urzad Statystyczny), mortality due to circulatory diseases in Poland is $46 \%$ (men: $41 \%$, women: $52 \%$ ) [2]. This remains the most frequent cause of death in our country, in spite of the downward trend observed over the last 20 years. Ischemic heart disease (IHD) mostly concerns elderly individuals and shows a predilection for male gender. However, younger patients can also suffer from

\section{Streszczenie}

Choroby układu sercowo-naczyniowego dotykają głównie osoby w wieku podeszłym, jednak coraz częściej chorują również młodzi. Szacuje się, że co 20. osoba z chorobą niedokrwienną serca jest w wieku poniżej 45 lat, a tylko $20 \%$ z nich to kobiety. Według danych rejestru PL-ACS, ostre zespoły wieńcowe u młodych kobiet stanowią 0,6\% wszystkich ostrych zespołów wieńcowych. Bez względu na wiek najczęstszą etiologię stanowi miażdżyca tętnic wieńcowych (80\%). Do innych przyczyn u młodych kobiet należą dyssekcje i kurcze tętnic wieńcowych czy też zaburzenia krzepnięcia. Spośród czynników ryzyka na pierwszym miejscu znajduje się nikotynizm a tuż za nim nadciśnienie tętnicze, hiperlipidemia i cukrzyca. Rokowanie odległe jest zazwyczaj korzystne, choć w momencie wystąpienia powikłań znacznie się pogarsza.

Literatura dotycząca tego tematu nie jest obszerna. Większość wiedzy jest oparta na badaniach bez randomizacji dotyczących ogólnie populacji młodej bez zróżnicowania ze względu na płeć. Celem tego opracowania jest przedstawienie problemu, jakim są ostre zespoły wieńcowe u młodych kobiet.

Słowa kluczowe: choroba wieńcowa, zawał, młode kobiety.

this disease, which happens with an increasing frequency. Among women, the prevalence is $<1 \%$, and among men $<5 \%$ of the population.

The problem of acute coronary syndromes (ACS) is becomingly increasingly widespread among young persons, resulting in a number of adverse health, social, and economic effects. The course of ACS in young people is slightly different than in the case of older individuals; this pertains both to women and men, though it is more pronounced among women. Regrettably, the literature on the subject is not very comprehensive. This stems from the fact that there are few cases of ACS among young women, and multicenter and long-term studies need to be designed in order to obtain study groups of sufficient size. There are only a few studies on the subject that focus specifically on women. Most data are acquired from studies in which male 
patients form a significant majority; these results are then extrapolated to the female population.

\section{Epidemiology}

Many authors report that young patients with ACS constitute $2-10 \%$ of all cases; most are men, while women constitute only approximately $25 \%$ of this patient population $[3,4]$. The difficulties with estimating the percentage of young ACS patients stem from the varying definitions of "youth". Different studies have used ages ranging from 35 to 55 to define its end. However, it appears justified to use the age of 45 as the appropriate threshold; this is particularly significant in the case of women, as this threshold enables the exclusion of the influence of hormonal disorders during menopause on the course of coronary artery disease. According to the conducted research, the mean age of menopause for Polish women is $51.25 \pm 2$ years [5]. The prevalence of ischemic heart disease among young women ( $\leq 45$ years) varies within the range of $0.1-1 \%$ of the population, but many authors underscore that it is underestimated [6]. Similar values are attributed to the number of ACS cases; only one in five young individuals with ACS is a woman. ACS epidemiology in Poland shows no significant differences from the image formed by data gathered around the world. Since 2004, 459,247 cases of ACS have been registered in the PL-ACS database; young individuals constitute $3.5 \%$ of cases, and the sex distribution was as follows: men $81.5 \%$, women $18.5 \%$. Young women constituted $0.6 \%$ of all cases [7].

\section{Pathogenesis}

The course of the disease and its consequences show a certain dependence on the patient's age. This pertains to risk factors, symptoms, diagnostics, treatment, and prognosis. The pathogenesis of ACS is similar for all populations regardless of age, race, or sex; only the proportions between them are different. Egred [6] established 4 main groups of ACS causes in young persons: 1) atheromatous coronary artery disease; 2) non-atheromatous coronary artery disease; 3) hypercoagulable states; 4) substance misuse.

Coronary artery atherosclerosis remains the most frequent cause of ACS: it is responsible for approximately $80 \%$ of all cases and is strictly associated with smoking tobacco and lipid metabolism disorders [8]. Atherosclerotic plaques in coronary vessels are found in $8 \%$ of women in their thirties; angiographic examinations typically reveal the involvement of a single vessel [6]. Although most researchers have not demonstrated any significance in relation to the distribution of the disease in individual vessels $[9,10]$, it appears to be much more common in the left coronary artery. According to Zimmerman [9], no significant lesions are found in as many as 34\% of young women undergoing angiography due to ACS; this percentage for the older population is only $18 \%$.

The risk factors that are most closely associated with the development of ACS are believed to include nicotinism, arterial hypertension, and lipid metabolism disorders
$[11,12]$. The INTERHEART study [12] indicates that the odds ratios (ORs) for the occurrence of myocardial infarction in young women exposed to individual risk factors are as follows: $\mathrm{OR}=2.86$ for nicotinism, $\mathrm{OR}=4.26$ for diabetes, $\mathrm{OR}=$ 2.95 for arterial hypertension, and $O R=2.26$ for abdominal obesity. Interestingly, the unfavorable association between diabetes/arterial hypertension and myocardial infarction is more pronounced in women than in men. Most authors point to smoking tobacco as the primary cause [9]. As many as $92 \%$ of young patients with atherosclerosis have nicotinism in their medical histories. The WHO MONICA study [13] reported that $77 \%$ of women treated for ACS between the ages of 35 and 39 were smokers. The relative risk (RR) for ACS occurrence in this group is 5.3 and is proportional to the number of smoked cigarettes [14]. According to Palmer et al. [15], a young woman ( $<55$ years) who smokes 25 cigarettes per day increases her risk of myocardial infarction 10-fold; as long as 5 years of abstinence is required for her risk to become equal to that of the general population.

Infarction without the presence of significant atherosclerotic lesions is much more common among young women in comparison to older patients. The most common causes include vascular dissection, the presence of myocardial bridges, congenital or acquired anatomical changes of the vessels, vascular spasms, and inflammatory vegetation. Dissections of the coronary vessels constitute a very important cause of ACS in women, especially young women, even though their prevalence ranges from $0.1 \%$ to $0.28 \%$. As many as $72 \%$ of dissection cases pertain to women, most frequently between the ages of 35 and 44 [16].

One should not forget about the increasingly frequent pathology in the form of ACS in the course of intoxication with substances such as cocaine, amphetamine, or cannabis; their strong constricting properties and the stimulation of the adrenergic system may result in myocardial infarction [6]. The largest number of events are observed after cocaine; apart from the aforementioned direct mechanism, it may also cause ACS indirectly by inducing cardiomyopathy, tachyarrhythmia, or infective endocarditis.

Another cause of infarction, whose frequency is insufficiently researched, is ACS in the course of neoplastic diseases. It may stem from a variety of factors: changes in cellular metabolism, activation of a number of proinflammatory and proliferative factors, deterioration of the rheological properties of blood, non-bacterial thrombotic endocarditis (NBTE), or cardiotoxic chemo- and radiotherapy. According to Ogawa et al. [17], as many as $6.5 \%$ of oncological patients had myocardial infarction confirmed in autopsy; the most frequent neoplasms included lung cancer and tumors of the head, neck, and the urinary tract.

It should be remembered that myocardial infarction may be the first manifestation of a neoplastic disease. Most often, this is a result of blood coagulation disorders, leading to coronary artery thrombosis and, consequently, type 1 myocardial infarction. Vascular thrombosis in the course of neoplastic diseases is not limited to coronary vessels, but may involve any blood vessel; it is known under the name 
Trousseau's syndrome. The prevalence of this syndrome ranges from 1 to $11 \%$ [18].

Nearly all antineoplastic agents are potentially cardiotoxic. Agents with documented ischemic action on the myocardium include cisplatin, capecitabine, fluorouracil, and vinca alkaloids. A large number of studies have been devoted to the evaluation of the influence of chest radiotherapy on the induction and course of coronary artery disease. According to Jagsi et al. [19], the risk of coronary artery disease induction is smaller than could be expected: the standard incidence ratio (SIR) of myocardial infarction in their study was 0.44 ( $95 \%$ confidence interval [CI]: 0.21-0.70), and the 10 -year risk for the occurrence of coronary artery disease after irradiation of the chest was $2.7 \%$, whereas for myocardial infarction it was $1.2 \%$. This is immensely important in the case of women, as radiation therapy is an indispensable element of breast-sparing therapy for mammary tumors, used mainly in the population of young women.

Hypercoagulable states deserve special attention in the female population [20-22]; they cause approximately $5 \%$ of myocardial infarctions and are often associated with the use of hormonal therapy (contraception) or with diseases of the connective tissue $[8,23]$. The most common include antiphospholipid syndrome, nephrotic syndrome, factor $\mathrm{V}$ Leiden gene mutation, and antithrombin III deficiency.

The issue of hormonal therapy is not thoroughly defined. On the one hand, estrogens are known to protect women from the occurrence of circulatory diseases after menopause, as illustrated by the fact that the incidence of ACS among women rises significantly after menopause due to the relative estrogen deficit. The strongest influence was observed within the first 3 years after menopause [24]. On the other hand, analysis of the population of young women using contraception shows that the risk of ACS rises significantly with the rise of estrogen content in contraceptive pills (RR 0.9 vs. 2.3 for a $40 \mu \mathrm{g}$ dose of ethinyl estradiol) regardless of progesterone content $[25,26]$. Oral use of progestogen-only contraceptives (POC) is not associated with an increased risk of ACS development $(R R=1.07)$ [27]. According to the data of the European Society of Human Reproduction and Embryology (ESHRE), the OR for ACS development in women using contraception is 2.5 and rises significantly in the case of concomitant arterial hypertension, obesity, or diabetes [26].

Interestingly, a significant role in the case of young women is played by family history. The results of the RATIO study [28] indicate that women with at least one parent who suffered from myocardial infarction are at 4 times higher risk of ACS with statistical CNS stroke risk. Also, stroke (hemorrhagic and ischemic) in the family history increases the risk of ACS two-fold without influencing the incidence of stroke $[28,29]$. The association is more pronounced in mother-daughter relationships than in fatherdaughter relationships. The phenomenon has not been observed in men. The research conducted by Patel et al. [30] indicates that women whose parents suffered from coronary events during young age $(<50$ years for men,
$<55$ years for women) have higher coronary calcium scores. Nonetheless, no relationship was observed in terms of the angiographic location of the atherosclerotic lesions.

Socio-economic status and level of education also play an important role in ACS etiology in women. These factors appear to have a stronger influence on the course of ACS in women than in men [31, 32]. Unfavorable prognostic factors include low economic and social status, lack of education, widowhood, type A personality, and high levels of everyday stress. Interestingly, unemployment does not constitute a risk factor for women (in contrast to men).

\section{Treatment and prognosis}

Many researchers devote their attention to the evaluation of prognosis and its unfavorable association with female sex. Reports published around the world indicate that the ACS prognosis is much worse for young women than for men of the same age (the mortality rate is twice as high), and as long as 10 years of disease progress is required for the prognoses to become similar. The OR for ACS ending with in-hospital death is 2.85 and is higher for women. The same has not been observed in the evaluation of long-term prognosis; the long-term values appear similar for both men and women: HR $=0.93$ [33]. Women more often present with intensified symptoms of heart failure at admission (Killip-Kimball classification). Only Killip classes III and IV were directly associated with poor early prognosis [4]. According to the authors of the CARDIA study [34], the risk of death associated with ACS rises with the reduction of left ventricular systolic function. When comparing women from different age groups, young age is a favorable prognostic factor, and total mortality rate is lower in younger patients: $3 \%$ vs. $12.3 \%(p<0.002)$ for mortality during the acute phase of ACS, and 3\% vs. $19.6 \%(p<0.001)$ for the later stage of the disease. This can probably be attributed to the greater burden of concomitant diseases in old age. The values presented above are directly proportional to the length of hospital stay (7.1 vs. $8.5 ; p=0.04)$ and morbidity (29.35\% vs. $39.7 \% ; p=0.02)$ [4].

The reasons why the prognosis in women is worse than in men are not fully understood. The phenomenon is attributed to factors including different symptomatology, delays in starting treatment (resulting from different disease perception among women, but also from lack of vigilance by physicians), and the use of different therapeutic schemes depending on the sex of the patient. The differences in disease perception have long been a subject of study. This also pertains to coronary artery disease. In the 1990s, Rosenfeld et al. [35] described a model for the meaning of illness for women with coronary heart disease ("theory of seeking understanding"). It consisted of 3 intertwined stages (denial, acknowledgement, fear) forming a vicious circle that delayed the diagnosis and the introduction of treatment, influencing further prognosis. Differences can also be found in the clinical manifestation of ACS in young women. Myocardial infarction is rarely preceded by a long disease history. According to British researchers, only $1 / 4$ of 
young women have a history of stable coronary artery disease preceding ACS [36], and 69\% of female patients deny having any anginal pain. In the remaining cases, the mean length of disease history was 10 days [37]. Studies by other authors indicate that only $3 \%$ of patients younger than 45 years (regardless of sex) with confirmed coronary atherosclerosis report coronary complaints $[10,38]$. The authors also noted an increased frequency of non-specific symptoms of unstable angina in this group of female patients, including deterioration of exercise tolerance, adynamia, and symptoms of increased activity of the autonomic nervous system (tachycardia, excessive sweating). The negative influence of healthcare on the prognosis cannot be excluded. Researchers underscore two aspects of this issue. The first is constituted by physicians delaying the introduction of invasive diagnostics, primarily due to the non-specificity of the symptoms in young patients and similarities to other, often more common causes of chest complaints in young individuals, e.g., pulmonary embolisms and inflammatory diseases of the heart. The other aspect consists in the disproportions between men and women in terms of invasive treatment. It is less keenly used in women, especially in NSTEMI patients. Factors claimed to be responsible for this phenomenon include the following: non-atherosclerotic causes of ACS, greater number of non-critical lesions, larger incidence of cardiac syndrome $X$, the occurrence of Takotsubo cardiomyopathy with increased perioperative risk for women, and more post-catheterization complications resulting from smaller vascular diameters, more frequent endothelial dysfunction, and larger vascular tortuosity in women [39].

\section{Conclusions}

This review of the literature shows that ACS in young women is rare and "governed by its own rules". The course of ACS in women is typically more severe and is associated with worse prognosis (especially early prognosis) than in the case of men of the same age. Non-atherosclerotic etiology of ischemic heart disease is more likely. There is a strong association between the presence of individual risk factors and the incidence of ACS, particularly with regard to nicotinism, arterial hypertension, and hyperlipidemia. Family history also plays an important role. As there is still little data concerning the course and prognosis of ACS in the population of young women, more studies and observations are required.

\section{Disclosure}

Authors report no conflict of interest.

\section{References}

1. Health statistics and health information systems. http://www.who.int/ healthinfo/statistics/mortality/en/index.html.

2. GUS http://demografia.stat.gov.pl/bazademografia/.

3. Doughty M, Mehta R, Bruckman D, Das S, Karavite D, Tsai T, Eagle K. Acute myocardial infarction in the young--The University of Michigan experience. Am Heart J 2002; 143: 56-62.
4. Chua SK, Hung HF, Shyu KG, Cheng JJ, Chiu CZ, Chang CM, Lin SC, Liou JY, Lo HM, Kuan P, Lee SH. Acute ST-elevation myocardial infarction in young patients: 15 years of experience in a single center. Clin Cardiol 2010; 33: 140-148.

5. Kaczmarek M. Określenie wieku menopauzy naturalnej w populacji polskich kobiet. Prz Menopauzalny 2007; 2: 77-82.

6. Egred M, Viswanathan G, Davis GK. Myocardial infarction in young adults. Postgrad Med J 2005; 81: 741-745.

7. Ogólnopolski Rejestr Ostrych Zespołów Wieńcowych PL-ACS.

8. Kornacewicz-Jach Z, Czechowska M, Stachowiak P. Zawał mięśnia sercowego u osób młodych. Kardiologia po Dyplomie 2012; 11: 7-16.

9. Zimmerman FH, Cameron A, Fisher LD, Ng G. Myocardial infarction in young adults: angiographic characterization, risk factors and prognosis (Coronary Artery Surgery Study Registry). J Am Coll Cardiol 1995; 26: 654-661.

10. Dou KF, Xu B, Yang YJ, Lü R, Qiu H, Yang WX, Mu ZW, Gao RL, Gao Z, Chen JL, Qiao SB, Li JJ, Qin XW, Liu HB, Wu YJ, Chen J, Yao M, You SJ, Yuan JQ, Dai J. Clinical and angiographic characteristics of premenopausal women with coronary artery disease. Chin Med J (Engl) 2008; 121: 2392-2396.

11. Gurevitz O, Jonas M, Boyko V, Rabinowitz B, Reicher-Reiss H. Clinical profile and long-term prognosis of women $<$ or $=50$ years of age referred for coronary angiography for evaluation of chest pain. Am J Cardiol 2000; 85: 806-809.

12. Anand SS, Islam S, Rosengren A, Franzosi MG, Steyn K, Yusufali AH, Keltai M, Diaz R, Rangarajan S, Yusuf S; INTERHEART Investigators. Risk factors for myocardial infarction in women and men: insights from the INTERHEART study. Eur Heart J 2008; 29: 932-940.

13. Mähönen MS, McElduff P, Dobson AJ, Kuulasmaa KA, Evans AE; WHO MONICA Project. Current smoking and the risk of non-fatal myocardial infarction in the WHO MONICA Project populations. Tob Control 2004; 13: 244-250.

14. Hbejan K. Smoking effect on ischemic heart disease in young patients. Heart Views 2011; 12: 1-6.

15. Palmer JR, Rosenberg L, Shapiro S. "Low yield" cigarettes and the risk of non fatal myocardial infarction in women. N Engl J Med 1989; 320: 1569-1573.

16. Besinger BR, Gardner S. Spontaneous coronary artery dissection in a 27-year-old woman. J Emerg Med 2013; 44: e239-e242.

17. Ogawa A, Kanda T, Sugihara S, Masumo H, Kobayashi I. Risk factors for myocardial infarction in cancer patients. J Med 1995; 26: 221-233.

18. Yang CM, Hsieh MY, Lin L, Wu CC. Acute myocardial infarctionin association with occult ovarian cancer. Acta Cardiol Sin 2013; 29: 102-106.

19. Jagsi R, Griffith KA, Koelling T, Roberts R, Pierce LJ. Rates of myocardial infarction and coronary artery disease and risk factors in patients treated with radiation therapy for early-stage breast cancer. Cancer 2007; 109: 650-657.

20. Tomaiuolo R, Bellia C, Caruso A, Di Fiore R, Quaranta S, Noto D, Cefalù AB, Di Micco P, Zarrilli F, Castaldo G, Averna MR, Ciaccio M. Prothrombotic gene variants as risk factors of acute myocardial infarction in young women. J Transl Med 2012; 10: 235.

21. Tanis B, Algra A, van der Graaf Y, Helmerhorst F, Rosendaal F. Procoagulant factors and the risk of myocardial infarction in young women. Eur J Haematol 2006; 77: 67-73.

22. Urbanus RT, Siegerink B, Roest M, Rosendaal FR, de Groot PG, Algra A. Antiphospholipid antibodies and risk of myocardial infarction and ischaemic stroke in young women in the RATIO study: a case-control study. Lancet Neurol 2009; 8: 998-1005.

23. Lindhardsen J, Ahlehoff O, Gislason GH, Madsen OR, Olesen JB, Torp-Pedersen C, Hansen PR. The risk of myocardial infarction in rheumatoid arthritis and diabetes mellitus: a Danish nationwide cohort study. Ann Rheum Dis 2011; 70: 929-934.

24. Lubiszewska B, Kruk M, Broda G, Ksieżycka E, Piotrowski W, Kurjata P, Zielinski T, Ploski R. The impact of early menopause on risk of coronary artery disease (PREmature Coronary Artery Disease In Women - PRECADIW casecontrol study). Eur J Prev Cardio 2012; 19: 95-101.

25. Lidegaard $\emptyset$, Løkkegaard E, Jensen A, Skovlund CW, Keiding N. Thrombotic stroke and myocardial infarction with hormonal contraception.N Engl J Med 2012; 366: 2257-2266.

26. ESHRE Capri Workshop Group. Hormones and cardiovascular health in women. Hum Reprod Update 2006; 12: 483-497.

27. Chakhtoura Z, Canonico M, Gompel A, Scarabin PY, Plu-Bureau G. Progestogen-only contraceptives and the risk of acute myocardial infarction: a meta-analysis. J Clin Endocrinol Metab 2011; 96: 1169-1174.

28. Siegerink B, Rosendaal FR, Algra A. Family history differs between young women with myocardial infarction and ischemic stroke: results from the RATIO case-control study. Atherosclerosis 2012; 223: 235-238. 
29. Banerjee A, Lim CC, Silver LE, Welch SJ, Banning AP, Rothwell PM. Familial history of stroke is associated with acute coronary syndromes in women. Circ Cardiovasc Genet 2011; 4: 9-15.

30. Patel MJ, de Lemos JA, Philips B, Murphy SA, Vaeth PC, McGuire DK, Khera A. Implications of family history of myocardial infarction in young women.Am Heart J 2007; 154: 454-460.

31. Koopman C, van Oeffelen AA, Bots ML, Engelfriet PM, Verschuren WM, van Rossem L, van Dis I, Capewell S, Vaartjes I. Neighbourhood socioeconomic inequalities in incidence of acute myocardial infarction: a cohort study quantifying age- and gender-specific differences in relative and absolute terms. BMC Public Health 2012; 12: 617.

32. Brezinka V, Kittel F. Psychosocial factors of coronary heart disease in women: a review.Soc Sci Med 1996; 42: 1351-1365.

33. Lawesson SS, Alfredsson J, Fredrikson M, Swahn E. A gender perspective on short- and long term mortality in ST-elevation myocardial infarction A report from the SWEDEHEART register. Int J Cardiol 2013; 168: 1041-1047.
34. Desai CS, Colangelo LA, Liu K, Jacobs DR Jr, Cook NL, Lloyd-Jones DM, Ogunyankin KO. Prevalence, prospective risk markers, and prognosis associated with the presence of left ventricular diastolic dysfunction in young adults: the coronary artery risk development in young adults study. Am J Epidemiol 2013; 177: 20-32.

35. Rosenfeld AG, Gilkeson J. Meaning of illness for women with coronary heart disease. Heart Lung 2000; 29: 105-112.

36. Chen L, Chester M, Kaski JC. Clinical factors and angiographic features associated with premature coronary artery disease. Chest 1995; 108: 364-369.

37. Butler R, Webster MW, Davies G, Kerr A, Bass N, Armstrong G, Stewart JT, Ruygrok $\mathrm{P}$, Ormiston J. Spontaneous dissection of native coronary arteries. Heart 2005; 91: 223-224.

38. Jalowiec DA, Hill JA. Myocardial infarction in the young and in women. Cardiovasc Clin 1989; 20: 197-206.

39. Krzemińska-Pakuła M. Czy płeć żeńska jest czynnikiem ryzyka w ostrych zespołach wieńcowych? Komentarz redakcyjny. Kardiol Pol 2011; 69: 793794. 